\title{
Molecular Assessment of the Introduction and Spread of Potato Cyst Nematode, Globodera rostochiensis, in Victoria, Australia
}

\author{
Mark J. Blacket, 1,2 Arati Agarwal,2 John Wainer,1,2 Maggie D. Triska, ${ }^{1,3}$ Michael Renton,1,3 and Jacqueline Edwards ${ }^{1,2,4, \dagger}$ \\ ${ }^{1}$ Plant Biosecurity Cooperative Research Centre, Canberra, ACT, Australia; ${ }^{2}$ Agriculture Victoria, AgriBio, 5 Ring Road, Bundoora, Victoria \\ 3083, Australia; ${ }^{3}$ The University of Western Australia, Crawley, WA, Australia; and ${ }^{4}$ La Trobe University, Bundoora, Victoria \\ 3083, Australia
}

Accepted for publication 24 September 2018.

\begin{abstract}
Potato cyst nematodes $(\mathrm{PCN})$ are damaging soilborne quarantine pests of potato in many parts of the world. There are two recognized species, Globodera pallida and G. rostochiensis, with only the latter species-the golden cyst nematode - present in Australia. PCN was first discovered in Australia in 1986 in Western Australia, where it was subsequently eradicated and area freedom for market access was reinstated. In Victoria, PCN was first detected in 1991 east of Melbourne. Since then, it has been found in a small number of localized regions to the south and east. Strict quarantine controls have been in place since each new detection. It has previously been speculated that there were multiple separate introductions of PCN into Victoria. Our study utilized a historic (years 2001 to 2014) PCN cyst reference collection to examine genetic variability of Victorian PCN populations to investigate potential historical origins and subsequent changes in the populations that might inform patterns of spread. DNA was extracted from single larvae dissected from eggs within cysts

and screened using nine previously described polymorphic microsatellite markers in two multiplex polymerase chain reaction assays. Sequence variation of the internal transcribed spacer region of the DNA was also assessed and compared with previously published data. A hierarchical sampling strategy was used, comparing variability of larvae within cysts, within paddocks, and between local regions. This sampling revealed very little differentiation between Victorian populations, which share the same microsatellite allelic variation, with differences between local regions probably reflecting changes in allele frequencies over time. Our molecular assessment supports a probable single localized introduction into Victoria followed by limited spread to nearby areas. The Australian PCN examined appear genetically distinct from populations previously sampled worldwide; thus, any new exotic incursions, potentially bringing in additional PCN pathotypes, should be easily differentiated from existing established local PCN populations.
\end{abstract}

Potato cyst nematodes (PCN) are damaging soilborne quarantine pests of potato in many parts of the world, including Australia (EPPO/CABI 1997; Moens et al. 2018). There are two recognized species-Globodera pallida, pale cyst nematode, and G. rostochiensis, golden cyst nematode-although only G. rostochiensis is present in Australia (Faggian et al. 2012). PCN are obligate, sedentary endoparasites that can cause stunting of plants, reduced yields, and sometimes complete crop failure. PCN causes losses of $9 \%$ of total potato production in Europe and can cause total losses in other regions of the world, or when no control strategies are employed (Turner and Subbotin 2013). When soil populations of PCN are high, potato yields can be less than the seed planted (Mai 1977; Whitehead and Turner 1998). This severe impact and the small size, cryptic nature, and long-term survival ability of PCN make it a very difficult pest to manage. PCN is recognized throughout the temperate regions of the world as one of the most difficult crop pests to control (Spears 1968).

Hosts of PCN are restricted to plants within the family Solanaceae. The potato (Solanum tuberosum) is by far the most important host. Tomato (S. lycopersicum) and eggplant (S. melongena)

†Corresponding author: J. Edwards; E-mail: jacky.edwards@ecodev.vic.gov.au

Funding: Financial support was provided by the Australian Government's Plant Biosecurity Co-operative Research Centre, Canberra, and the State Government of Victoria.

*The $\boldsymbol{e}$-Xtra logo stands for "electronic extra" and indicates that two supplementary figures and two supplementary tables are published online.

The author(s) declare no conflict of interest.

This article is in the public domain and not copyrightable. It may be freely reprinted with customary crediting of the source. The American Phytopathological Society, 2019. are also attacked, and 90 other Solanum spp. and their hybrids can also act as hosts, including Solanum weed species (CABI 2016; van Riel and Mulder 1998) and the Australian native kangaroo apple (S. aviculare) (Faggian et al. 2012). The significance of weed species as refuges for PCN severely affects the success of any regulatory procedures (Mimee et al. 2014).

PCN is recognized as a significant global threat to food security (Cotton et al. 2014) and, as such, is the subject of stringent quarantine regulations in most countries where it occurs (EPPO/CABI 1997). Countries not known to be infested with PCN have rigid regulations governing the importation of host material or other products that might carry the pest (Brodie 1998; Hockland et al. 2013; Spears 1968). Therefore, the presence of the golden cyst nematode in Australia has had serious implications for market access and international trade of seed potato, which is managed accordingly (DEDJTR 2016). For example, exacting restrictions are placed on the movement of seed potato grown in Victoria (DPIPWE 2015; PBPI-BQ 2016; PBPPIS 2016; PIRSA 2015).

The Australian potato industry produces approximately 1.33 million $\mathrm{t}$ of processed, fresh, and seed potato from approximately 28,000 ha. In 2016 to 2017, Australian production was valued at AUS\$717 million; the Victorian potato industry produced 282,000 t, approximately $21 \%$ of the total Australian crop, which was valued at AUS $\$ 152$ million (HIA 2018). During the same time period, Australia exported $38,000 \mathrm{t}$ of potato worth AUS $\$ 38$ million, which was Australia's third most valuable vegetable export commodity (AUSVEG 2018); however, Victoria contributed only 3\% to this export market supply. The estimated losses to the Australian potato industry if no quarantine actions were taken to prevent PCN spread or entry to new areas were estimated by Hodda and Cook (2009) to be AUS\$20 million annually, and as much as AUS $\$ 370$ million over 20 years.

In some countries, land in which PCN is detected is not eligible for seed potato production for many years. For example, infested 
land in Northern Ireland is not eligible even to be sampled until at least 15 years from the last potato crop and, if it is still infested thereafter, it is only eligible to be resampled every 5 years until declared free from PCN (Lehman 2004; Whitehead and Turner 1998). In Scotland, land is scheduled if official sampling finds one or more viable cysts of PCN. Thereafter, the land becomes eligible for descheduling after a period of between 1 and 6 years, depending upon the species and number of cysts found (Pickup and Hockland 2002). The Canadian Food Inspection Agency and the United States Department of Agriculture Animal and Plant Health Inspection Service have jointly prepared guidelines on the surveillance and phytosanitary actions for PCN (USDA 2014). These guidelines provide detailed instructions for the surveillance and phytosanitary measures that are required to deregulate infested, adjacent, and exposed fields. In summary, infested fields are eligible for the lifting of some restrictions when intensive surveys, viability assays, and bioassays are completed with no live detections. Seed potato production in a field which was determined to be infested with PCN is not allowed if they are going to be planted outside of the PCN regulated area. If results are negative, an additional four full field surveys must be conducted before most restrictions can be lifted. Kepich (2011) reported that, in the United States, state and federal

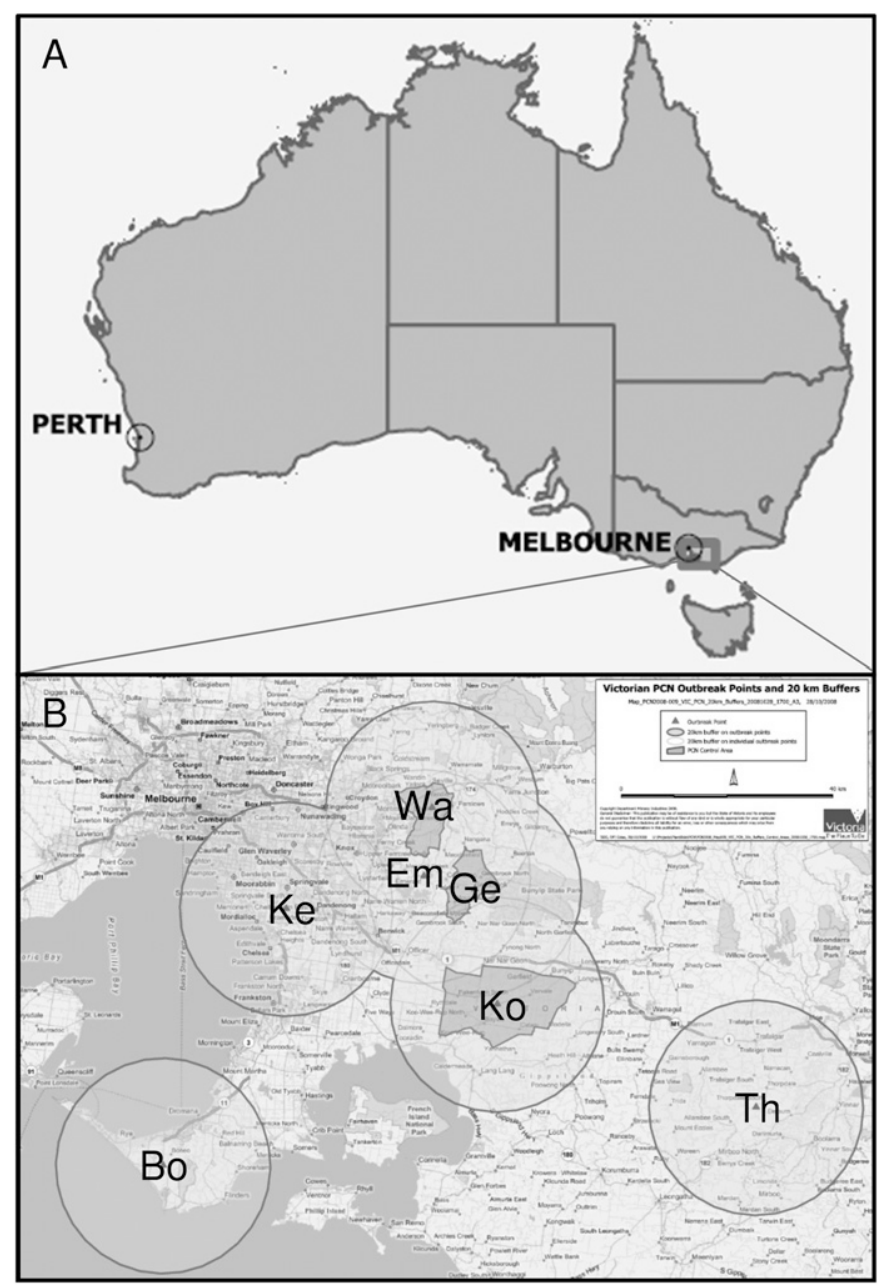

Fig. 1. A, Map of Australia indicating the locations of potato cyst nematode (PCN) incursions in Western Australia (Perth, now eradicated) and Victoria (Melbourne, currently established); lines on map indicate Australian state boundaries. B, Victorian quarantine zones (gray) and 20-km controlled areas (circles) which historically involved restricted movement of potato material and extra hygiene restrictions around PCN outbreaks. Location abbreviations: $\mathrm{Bo}=\mathrm{Boneo}, \mathrm{Em}=$ Emerald, $\mathrm{Ge}=$ Gembrook, $\mathrm{Ke}=$ Keysborough, $\mathrm{Ko}=\mathrm{Koo}$ Wee Rup/Cora Lynn, To = Thorpdale, and Wa = Wandin. regulatory agencies had a 5-year plan with the goal of deregulating up to $90 \%$ of quarantined area by the end of 2014 .

The golden cyst nematode ( $G$. rostochiensis) was first discovered in Australia in September 1986 in Munster, a suburb near Perth, Western Australia (Fig. 1A). Western Australia had a total of six PCN-infested properties within a 5-km radius (Stanton 1986). An eradication program was implemented soon after detection, resulting in no further detections of PCN since 1989. After 24 years of continued surveillance, eradication of the nematode from Western Australia was declared and area freedom from PCN for market access was successfully reinstated in 2010 (Collins et al. 2010).

In Victoria, G. rostochiensis was first detected in a potato crop showing early senescence in a small market garden at Wandin in February 1991 (Guy et al. 1992). As a result of subsequent intensive surveys, PCN was found at several additional locations east and south of Melbourne, including Gembrook (in 1991), Emerald (1992), Keysborough (1992), Boneo (1992), Koo Wee Rup/Cora Lynn (2003), and, most recently, near Thorpdale (2008) (Fig. 1B). The second economically significant species of PCN, pale cyst nematode $(G$. pallida) has never been recorded in Australia (Faggian et al. 2012). Similarly, other species of Globodera that can feed on potato (e.g., G. tabacum solanacearum, G. ellingtonae, and $G$. leptonepia) have not been recorded in Australia.

In both Australian states, the first detections were the result of growers observing poor growth and plant collapse in their fields. Such visible symptoms (Fig. 2A and B) suggest that the infestations may have been present for some time before detection (Mai 1977; Spears 1968).

In Victoria, quarantine control areas were established around the Gembrook, Wandin, Koo Wee Rup, Keysborough, Thorpdale, and Boneo PCN infestations (Fig. 1B). Area freedom for the remainder of Victoria is based on 57,000 PCN soil tests taken between 1991 and 2018 from surveys covering 29,000 ha of potato production throughout Victoria. In 2013, all Australian states except Western Australia accepted a risk-based PCN management program, which provides industry and government a harmonized management system to minimize the risk of spreading the pest while allowing market access for potato (AUSVEG 2012). An important implication of this recently implemented risk-based model is that interstate quarantine controls which were based on the treatment and certification of all host produce sourced from within $20 \mathrm{~km}$ of a known PCN detection were replaced by property-based controls. Prior to 2013, phytosanitary certificates for export of Victorian potato to overseas markets were only issued for potato grown outside a $20-\mathrm{km}$ radius zone of an infested property (AUSVEG 2012). The changes aimed to ease trade restrictions for properties within the $20-\mathrm{km}$ zone that were not historically infested or linked in some way (e.g., by ownership, shared machinery, or shared watercourses) to infested properties. The changes also created a national standard for the distribution of PCN host material and management practices for reducing the biosecurity risks associated with spreading the pest (AUSVEG 2012). Both infested and associated linked lands are still subject to several prohibitions, restrictions, and requirements that affect the use of that land and market access for produce grown there. PCN host material originating from land classified as uninfested no longer requires certification for interstate access, except for Western Australia, whereas all potato tubers marketed as seed or for planting are tested for PCN prior to interstate movement (DEPI 2013).

The Victorian Certified Seed Potato Authority (ViCSPA) Seed Potato Certification Scheme provides for production of highquality certified seed potato reliably free of PCN, allowing for exportation clearance of seed potato for trade. All ViCSPA-certified seed crops must be soil sampled for PCN and tested negative. Certified seed potato production under the ViCSPA scheme covers an area of 1,900 ha with approximately 85 growers (ViCSPA 2015). The traceability and high health record of Australia's seed potato certification system led to the acquisition in 2018 of new market 
access to Indonesia for approximately 85,000 t of Australian seed potato worth AUS\$110 million (Laskie 2018).

The most likely way that PCN is transported to new localities is by the cysts in soil adhering to potato tubers, because loose cysts can be embedded in tuber eyes or other irregularities on the tuber (Anon 2007). In addition, cysts can be carried in soil adhering to farm machinery, implements, boots, potato bins, plant roots, and, particularly, bulbs (Been and Schomaker 2013; Pendrigh 1993; Turner and Evans 1998). Cysts can also be spread by wind and water (CABI 2016; Persley et al. 2010; Riggs and Schuster 1998; Turner and Evans 1998). On a local level, PCN is usually spread by farming activities such as sharing farm equipment contaminated with infested soil. Initial sampling after the first Victorian detection of PCN led Marshall (1998) to comment that "Family connections and the sharing of seed and potato boxes linked all properties. Two of the infested properties at Wandin East were adjoining, and two were farmed in association".

Understanding dispersal modes and genetic links between populations is essential to prevent further spread and to develop effective control strategies. Picard et al. (2004) found that, in its native habitat, $G$. pallida showed extensive gene flow between fields, and they suggested that this was a result of passive dispersal of cysts by natural means (wind, running water, or wild animals) or by anthropogenic means (tillage or movement of infected seed tubers). On the other hand, they noted that it is difficult to study the population genetics of an introduced organism such as PCN because the current genetic structure could have already been influenced by several factors such as (i) number of individuals that were introduced; (ii) number of generations since introduction; (iii) origin and, thus, genotypes of the individuals introduced; and (iv) stochastic effect of genetic drift.

At least five G. rostochiensis pathotypes are known to exist (Ro1 to Ro5), which have different abilities to infect certain tuberous Solanum hosts (which are used as differentials to distinguish pathotypes) (EPPO/CABI 1997; Kort et al. 1977). The only pathotype recorded in Australia is Ro1 (Hinch et al. 1998; Nambiar et al.2008), to which most commonly grown resistant cultivars have resistance (Faggian et al. 2012).

In a molecular examination of the internal transcribed spacer (ITS) region of DNA in G. rostochiensis, Bulman and Marshall (1997) found no variation within Australasian collections, which they suggested originated in Europe. Conversely, sequence analysis by Nambiar et al. (2008) revealed the presence of genetically diverse populations in infested fields in Victoria, from which they suggested the possibility of up to seven separate introductions. Determining whether there has been more than one introduction has practical importance for the management of PCN. It is important to be able to recognize new outbreaks, because the genetic basis of PCN virulence (i.e., pathotypes) may differ (Grenier et al. 2001). Nambiar et al. (2008) examined genetic variation of the ITS region by sequencing whole cysts containing potentially up to several hundred eggs, rather than single larvae. They chose 87 cysts from seven locations representing two localized regions in Victoria (Gembrook and Koo Wee Rup) separated from each other by approximately $20 \mathrm{~km}$. All isolates were grouped into six genotypic groups. Victorian isolates were found to be different from the European and American genotypes recorded in GenBank at that time. They noted that $G$. rostochiensis from different properties of the same grower were placed into separate genotypic groups.

Fertilization is essential for reproduction in Globodera spp. (Turner and Evans 1998) and, because cyst nematodes practice polyandry, the genetic diversity within a single cyst that can contain hundreds of individuals should be high (Mimee et al. 2015). In the G. pallida invasion of Western Europe, as much genetic variability occurred in the PCN on a single plant as in a field or even a whole region (Plantard et al. 2008). Hence, introduction via a single infested potato plant could result in relatively high genetic variability.
To study the genetic structure and evolution of G. rostochiensis and G. pallida in Canada, Boucher et al. (2013) used whole-genome sequencing of individual larvae to identify 12 polymorphic microsatellite markers informative enough for the purpose. Extracting DNA from individual juveniles dissected from cysts, they could genotype populations originating from 15 populations from around the world. This enabled them to characterize genetic
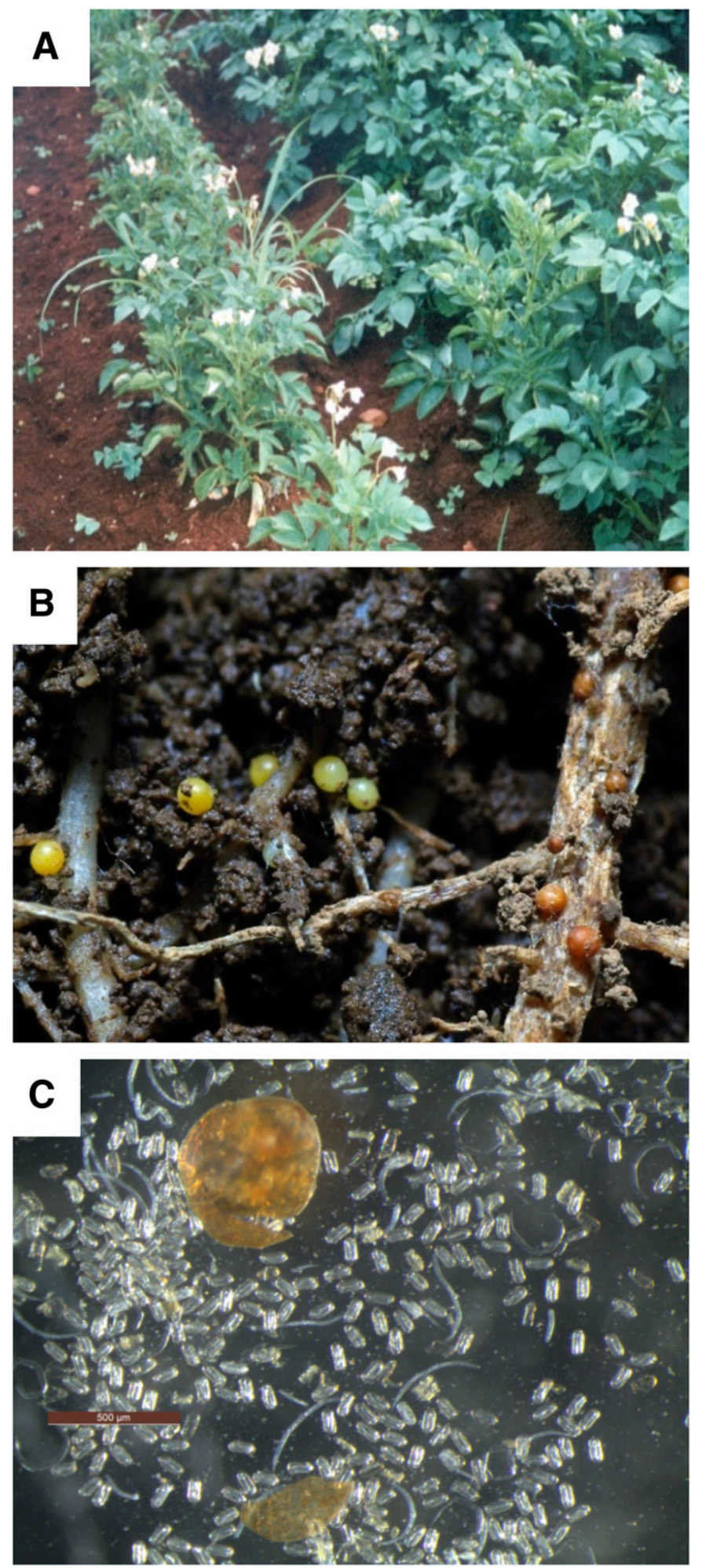

Fig. 2. A, Potato cyst nematode $(\mathrm{PCN})$ infestation symptoms in a Victorian market crop; plants on left are stunted due to a heavy PCN infestation. B, PCNinfested roots under high magnification. Cysts, the bodies of female nematodes containing nematode eggs, are initially yellow and darken with age. C, Cyst dissection showing eggs and released juveniles. Images: Agriculture Victoria. 
links between these populations, and to reveal the history of introductions and dispersal within Canada. Subsequently, Alenda et al. (2014) used the nine most informative of these microsatellite marker sets to explore the dispersal and genetic structure of populations of another nematode species, G. tabacum, in France. This study showed that human activity in the form of soil transport during harvest was the major factor contributing to the passive dispersal of these organisms.

The Victorian government plant diagnostic laboratory, Crop Health Services, has been responsible for all PCN testing undertaken in Victoria. As a result, a reference collection of cysts from each positive detection since 1991 has been maintained, with full collection and location details for each. Early cyst collections were preserved in formaldehyde and were unable to be utilized but more recent collections (post-2000) have been stored dry at room temperature. In this investigation, our objectives were to use this historic cyst reference collection to genetically characterize Victorian populations of $G$. rostochiensis using polymorphic microsatellite markers as well as sequences from the ITS region to investigate the introduction, history, and spread of this pest in Victoria.

\section{MATERIALS AND METHODS}

Field sampling and nematode extraction. During monitoring and detection surveys for PCN, soil was collected using a 10-by$10-\mathrm{m}$ sampling pattern, where $100-\mathrm{by}-10-\mathrm{cm}^{3}$ cores to a depth of $10 \mathrm{~cm}$ were taken per hectare. Two hundred cores per 2 ha were combined and mixed, from which a subsample of $0.5 \mathrm{~kg}$ was used for PCN cyst extraction (Hinch 1991). Cysts were extracted from soil using Fenwick cans (Fenwick 1940). Cysts containing unhatched eggs and larvae were placed each in a drop of purified water on a cleaned microscope slide and were broken using two sets of fine forceps to release the contents. Using a Leica M205C microscope (magnification $\times 30$ ), single larvae were extracted from eggs within the cysts using a fine probe and placed in $20 \mu \mathrm{l}$ of purified water in 1.1-ml eight-strip minitubes (Neptune). When cysts were abundant, one larva was selected from each of 16 cysts from each paddock. Where fewer than 16 cysts were available per paddock, a total of eight larvae were selected from each cyst. From one of the Gembrook paddocks where plentiful cysts were available, eight larvae were selected from each of 24 cysts.

Nematode populations used in this study. In this study, we utilized the PCN cyst reference collection (VPRI) held by Crop Health Services, Agriculture Victoria, to examine the genetic variability of Victorian PCN populations. A hierarchical sampling strategy was used to compare variability of juveniles within cysts, within and across paddocks, and between regions (Supplementary Table S1). In total, 944 juveniles were collected from four regions: Gembrook $(n=592)$, including a large sample from one crop variety trial site within Gembrook $(n=384)$; Koo Wee Rup $(n=208)$; Boneo $(n=24)$; and Thorpdale $(n=120)$.

DNA extraction and detection by real-time quantitative polymerase chain reaction. The total genomic DNA was extracted from single juveniles following the method described by Boucher et al. (2013). The real-time quantitative polymerase chain reaction (qPCR) primer (Sigma) and probe set (Applied Biosystems) designed by Reid et al. (2010) was used to check the quality and quantity of the PCN DNA samples (Table 1). Real-time qPCR was performed in a Rotor-Gene Q (Qiagen) in a total volume of $12.5 \mu \mathrm{l}$. Each reaction mixture included $6.25 \mu$ of Platinum Quantitative PCR SuperMix-UDG (Invitrogen), $0.3 \mu \mathrm{M}$ each forward and reverse primer, $0.1 \mu \mathrm{M}$ Taqman probe, and $2 \mu \mathrm{l}$ of template DNA, made up to $12.5 \mu \mathrm{l}$ with RNA-free water. A nontemplate control with $2 \mu \mathrm{l}$ of water instead of DNA and a positive control (DNA extracted from 100 PCN juveniles) was included in each run. The PCR thermal cycling conditions consisted of a two-step denaturation: $2 \mathrm{~min}$ at $50^{\circ} \mathrm{C}$ and $10 \mathrm{~min}$ at $95^{\circ} \mathrm{C}$, followed by 40 cycles of amplification in a two-step procedure: $95^{\circ} \mathrm{C}$ for $15 \mathrm{~s}$ and $60^{\circ} \mathrm{C}$ for $30 \mathrm{~s}$. The threshold cycle $(\mathrm{Ct})$ value of the positive control was used as a comparison to determine the presence or absence of PCN DNA and eventually estimate its quality and quantity in unknown samples.

PCR amplification and genotyping. DNA samples which were detected as positive (qPCR) with good DNA yields were then processed for microsatellite PCR amplification and genotyping. PCR was conducted using nine microsatellite markers developed by Boucher et al. (2013): seven developed from G. rostochiensis (Gr50, Gr67, Gr75, Gr85, Gr90, Gr91, and Gr96) and two from G. pallida (Gp116 and Gp118) (Table 2). We originally tested four additional

TABLE 1. List of primers and probe used for potato cyst nematode DNA detection (quantitative polymerase chain reaction) and for sequencing the ribosomal gene spacer region ${ }^{\mathrm{a}}$

\begin{tabular}{|c|c|c|c|c|}
\hline Oligo name $\mathrm{b}^{\mathrm{b}}$ & Forward primer sequences $\left(5^{\prime}-3^{\prime}\right)$ & Reverse primer sequences $\left(5^{\prime}-3^{\prime}\right)$ & Probe $\left(5^{\prime}-3^{\prime}\right)$ & Reference \\
\hline Globod & CGTTTGTTGTTGACGGACAYA & GGCGCTGTCCRTACATTGTTG & CCGCTGTGTATKGGC & Reid et al. 2010 \\
\hline $\begin{array}{l}\text { ITS5 } \\
\text { ITS26 }\end{array}$ & $\begin{array}{c}\text { GGAAGTAAAAGTCGTAACAAG } \\
\ldots\end{array}$ & ATATGCTTAAGTTCAGCGGGT & $\begin{array}{l}\cdots \\
\cdots\end{array}$ & $\begin{array}{l}\text { White et al. } 1990 \\
\text { Howlett et al. } 1992\end{array}$ \\
\hline
\end{tabular}

a All primers were ordered online from Sigma-Aldrich and the TaqMan probe from Applied Biosystems.

b ITS = internal transcribed spacer.

TABLE 2. Characteristics of nine microsatellite markers used in this study for Australian population genetic diversity analysis of Globodera rostochiensis (Boucher et al. 2013)

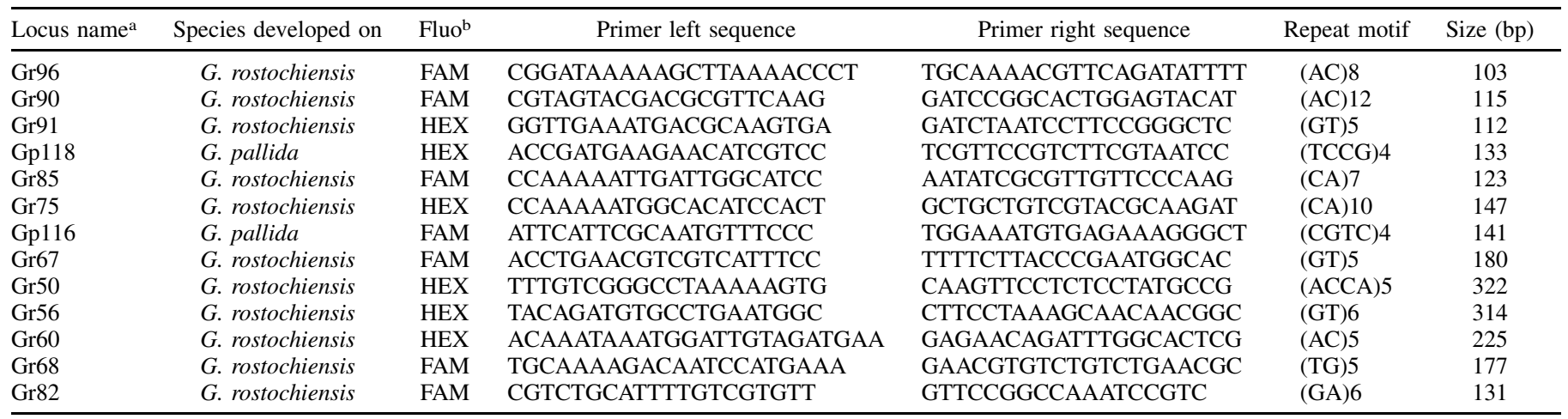

a Abbreviations: $\mathrm{Gr}=$ isolated from G. rostochiensis and $\mathrm{Gp}=$ isolated from G. pallida.

b Fluorophore. Note that HEX is equivalent to VIC. 
G. rostochiensis microsatellite markers employed by Alenda et al. (2014) (Gr56, Gr60, Gr68, and Gr82) but these were found to possess insufficient variation to discriminate Victorian G. rostochiensis populations (data not shown). All primers were synthesized (Sigma) and the 5' ends of the forward primers were labeled with two fluorescent dyes (6-FAM and HEX). PCR reagents, volume, and cycling conditions used were according to Boucher et al. (2013). All PCR amplifications were conducted on a Veriti 96-well Thermal Cycler (Applied Biosystems). Each primer pair was first tested by running PCR in simplex. The PCR products were diluted $1: 10$ in ultrapure water, with $2 \mu \mathrm{l}$ of the dilution mixed with $8 \mu \mathrm{l}$ of GeneScan-500 LIZ size standard (Applied Biosystems) plus Hi-Di formamide. Chromatograms showing PCR product sizes were produced using an ABI PRISM 3730xl automated sequencer (Applied Biosystems). Allele sizes of the fragments were scored by manual identification of the peaks for the presence or absence of the corresponding chromatogram using the software Geneious v9.1.3. Following this, all DNA samples were genotyped in two multiplex combinations: multiplex 1 had four markers (Gr67, Gr75, Gr90, and Gp118) and multiplex 2 had five markers (Gr50, Gr85, Gr91, Gr96, and Gp116).

To ensure that base pair sizes were determined accurately, allele sizes were confirmed through sequencing PCR products of homozygous alleles commercially through Macrogen. The forward primers for each of the nine primer sets were synthesized (Sigma) without the fluorescent dyes. Duplicate DNA samples were processed for primers Gr50, Gr67, Gr75, Gr85, Gr90, and Gp118 and quadruplicates for primers Gr91, Gr96, and Gp116. Standard PCR was performed in a Veriti 96-well Thermal Cycler (Applied Biosystems) in a total volume of $25 \mu \mathrm{l}$. Each PCR contained 1x Standard Taq reaction buffer, $200 \mu \mathrm{M}$ dNTP, $5 \mathrm{mM} \mathrm{MgCl}_{2}, 2 \mathrm{U}$ of Taq DNA Polymerase (Invitrogen), $0.18 \mu \mathrm{M}$ each forward and reverse primers, and $5 \mu \mathrm{l}$ of template DNA, and was made up to $25 \mu \mathrm{l}$ with RNA-free water. A nontemplate control with $5 \mu$ l of water instead of DNA was included for each primer set. The PCR thermal cycling conditions were as follows: initial denaturation step at $95^{\circ} \mathrm{C}$ for $10 \mathrm{~min}$; followed by 45 cycles of denaturation at $95^{\circ} \mathrm{C}$ for $30 \mathrm{~s}$, annealing at $57^{\circ} \mathrm{C}$ for $1 \mathrm{~min} 30 \mathrm{~s}$, and extension at $72^{\circ} \mathrm{C}$ for $30 \mathrm{~s}$; and a final extension at $60^{\circ} \mathrm{C}$ for $30 \mathrm{~min}$. To confirm the presence and the size of the band, $5 \mu \mathrm{l}$ of the PCR product of all the samples was separated on a $2 \%$ agarose gel stained with $1 \times$ SYBR Safe DNA (Invitrogen). The gel was visualized under UV light using Gel Doc EZ System (Bio-Rad). The sizes of the amplicons were estimated using a 100-bp ladder (Invitrogen). Each PCR product ( $20 \mu \mathrm{l})$ was sent for sequencing to Macrogen. Forward and reverse sequences for each sample were analyzed using the software Geneious v9.1.3 and allele size was determined.

PCR amplification for ITS sequencing. The ribosomal gene spacer region was amplified using primers ITS5 and ITS26 (Table 1), as described by Bulman and Marshall (1997) and Nambiar et al. (2008). In total, 28 DNA samples were processed for sequencing from the four regions: Gembrook $(n=13)$, Koo Wee Rup $(n=7)$, Boneo $(n=2)$, and Thorpdale $(n=6)$.

Standard PCR was performed in a Veriti 96-well Thermal Cycler (Applied Biosystems) in a total volume of $25 \mu \mathrm{l}$. Each PCR contained $1 \times$ Standard Taq reaction buffer, $200 \mu \mathrm{M}$ dNTP, $5 \mathrm{mM}$ $\mathrm{MgCl}_{2}, 2 \mathrm{U}$ of Taq DNA Polymerase (Invitrogen), $0.18 \mu \mathrm{M}$ each forward and reverse primers, and $5 \mu \mathrm{l}$ of template DNA, and was made up to $25 \mu \mathrm{l}$ with RNA-free water. A nontemplate control with $5 \mu \mathrm{l}$ of water instead of DNA was included in the run. PCR cycling conditions were as follows: initial denaturation step at $95^{\circ} \mathrm{C}$ for 10 min followed by 45 cycles of denaturation at $95^{\circ} \mathrm{C}$ for $30 \mathrm{~s}$, annealing at $55^{\circ} \mathrm{C}$ for $30 \mathrm{~s}$, and extension at $72^{\circ} \mathrm{C}$ for $30 \mathrm{~s}$. To confirm the presence and the size of the band, $5 \mu \mathrm{l}$ of the PCR product of all 28 samples was separated on a $2 \%$ agarose gel stained with 1× SYBR Safe DNA (Invitrogen). The gel was visualized under UV light using Gel Doc EZ System (Bio-Rad). The sizes of the amplicons were estimated using a 100-bp ladder (Invitrogen).
Each PCR product $(20 \mu \mathrm{l})$ was sent for sequencing to Macrogen. Forward and reverse sequences for each sample were aligned and edited using the Geneious software v9.1.3.

Analyses of molecular variation. Microsatellite variation was analyzed for both population differentiation, estimated through pairwise Fst and levels of population structure, and levels of geneflow between populations, calculated from an analysis of molecular variance (AMOVA), conducted in GenAlEx 6.502 (Peakall and Smouse 2006, 2012). Patterns of population structure and admixture were also estimated using a Bayesian model-based clustering method implemented in STRUCTURE, version 2.3.4 (Falush et al. 2003; Pritchard et al. 2000), employing 25,000 replicates, with a burn-in of 500 and up to 10 populations $(K=1$ to 10). Relationships between Australian PCN and worldwide populations (Boucher et al. 2013) were also examined through generating Nei's genetic distances between populations in GenAlEx, analyzed as a neighbor-joining tree in MEGA, version 7.0.26 (Kumar et al. 2016). Departures from Hardy-Weinberg equilibrium within each Australian population were examined by performing a $\chi^{2}$ test in Excel 2016 to examine variation of microsatellite genotype frequencies at a site examined over time (2008 to 2010).

All publicly available ITS DNA sequences, with greater than $70 \%$ query coverage of the ITS sequences generated in the current study, were obtained from GenBank. Combined sequences were aligned using ClustalW with genetic relationships analyzed through generating a neighbor-joining tree, in MEGA.

Further genetic analyses were conducted in $\mathrm{R}$ ( $\mathrm{R}$ Core Team 2017). Distance-based redundancy analysis was used to test for differences (i) among all populations and (ii) between all Australian and all non-Australian populations using the Adonis function in the $R$ vegan package (Anderson 2001; Oksanen et al. 2016; Zapala and Schork 2006). Nonmetric multidimensional scaling ordination was used to visualize variation, similarities, and differences among samples and populations using the metaMDS function in the $\mathrm{R}$ vegan package (Minchin 1987).

\section{RESULTS}

Genotyping. Of the 944 juveniles extracted, approximately one-third (32\%) produced DNA that could be amplified for examination of microsatellites. Of these, $88 \%$ (265 individuals) produced complete genotypes for all microsatellite markers examined (Supplementary Table S2). DNA was successfully extracted from cysts from 14 paddocks at Gembrook, 12 at Koo Wee Rup, 6 at Thorpdale, and 1 at Boneo.

Absolute microsatellite allele sizes (in base pairs) were determined through DNA sequencing homozygotes (Table 3). However, it was found necessary to adjust the size of alleles to match previously published allele sizes for comparison with worldwide genotypic data (Boucher et al. 2013) (see below).

Population structure. Analyses of population structure between Australian and worldwide PCN populations, using the nine microsatellites screened in the current study (Fig. 3; Supplementary Fig. S1), detected the same clusters of populations worldwide as had been previously reported through analyses of a larger number of microsatellites (Boucher et al. 2013). However, these analyses did not reveal any apparent population structure between Australian populations. A close association of Australian populations to any worldwide population included in the analyses was also not indicated (Figs. 3, 4, and 5). Analyses allowing for a larger number of potential populations (e.g., $K=10$ ) (Fig. 3 ) still did not provide strong evidence of population differentiation within Australia.

No microsatellite alleles were found to be unique among Australian putative populations. Additional evidence for a lack of population structure within Australian populations was also shown by the percentage of AMOVA. AMOVA revealed that, when overall PCN populations (worldwide and Australian) were 
analyzed together, a large amount of variation was observed among populations $(51 \%)$ and individuals $(41 \%)$, with very little within individuals $(8 \%)$. On the other hand, when only the four Australian regions were analyzed together, the variation among populations was found to be very low (10\%), with most variation being found within populations $(37 \%)$ and individuals $(53 \%)$. Distance-based redundancy analysis provided strong support for differences among populations $(P<0.001)$ and between Australian and non-Australian populations $(P<0.001)$, and this was supported by the nonmetric multidimensional scaling ordination (Fig. 5).

Origin of Australian PCN populations. The microsatellite analyses did not indicate a strong relationship between the Australian PCN populations and any of the worldwide populations that have been previously screened (Figs. 3, 4, 5, and 6; Supplementary Fig. S2), with the allelic variation observed in the current study consisting predominantly of the most common alleles known worldwide (Table 3). Analyses of ITS DNA sequence variation confirmed Australian $\mathrm{PCN}$ to be $G$. rostochiensis
(Fig. 7), with Australian PCN samples exhibiting relatively low genetic variation for the ITS gene and appearing to be most closely related to samples that were predominantly collected from Europe (Fig. 7). GenBank accession numbers for ITS DNA sequences obtained in the current study are MH820358 to MH820362.

Variation in an Australian PCN population. The most comprehensively sampled Australian region, both temporally and spatially, was Gembrook. At the Gembrook potato variety trial site, sampled between 2008 and 2010, microsatellite data were successfully obtained from 62 juveniles from 16 cysts. An AMOVA of these samples reveals that only $6 \%$ of the genetic variation was localized within paddocks, while the great majority existed within individuals (78\%) and among individual cysts (16\%). Differences between crop varieties were observed in microsatellite genotype frequencies, including several departures from Hardy-Weinberg equilibrium within paddocks (Fig. 8). Additionally, microsatellite allele frequency variation was observed within PCN cysts collected from Gembrook (Fig. 9).

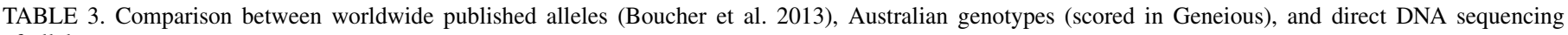
of alleles

\begin{tabular}{|c|c|c|c|c|c|c|c|c|c|c|c|}
\hline \multirow{2}{*}{$\begin{array}{l}\text { Locus } \\
\text { name }\end{array}$} & \multirow{2}{*}{$\begin{array}{l}\text { Original sequenced } \\
\text { allele (base pairs, } \\
\text { repeat motif) }\end{array}$} & \multirow{2}{*}{$\begin{array}{l}\text { Published } \\
\text { allele } \\
\text { size (bp) }\end{array}$} & \multirow{2}{*}{$\begin{array}{l}\text { Geneious } \\
\text { allele } \\
\text { size (bp) }\end{array}$} & \multirow{2}{*}{$\begin{array}{c}\text { DNA } \\
\text { sequence } \\
\text { allele size } \\
\text { (bp) }\end{array}$} & \multirow{2}{*}{$\begin{array}{l}\text { Observed } \\
\text { repeat } \\
\text { motif }^{\mathrm{b}}\end{array}$} & \multirow{2}{*}{$\begin{array}{c}\text { GenBank } \\
\text { accession }^{\mathrm{b}}\end{array}$} & \multirow{2}{*}{$\begin{array}{c}\text { Most } \\
\text { common } \\
\text { allele } \\
\text { worldwide } \\
\text { (bp) }\end{array}$} & \multicolumn{4}{|c|}{ Genotypes (bp) in Australia ${ }^{a}$} \\
\hline & & & & & & & & 1 & 2 & 3 & 4 \\
\hline Gr96 & 103, (AC)8 & 93 & 92 & 93 & $(\mathrm{AC}) 3$ & MH820363 & Yes: 93 & 9393 & 9399 & 9999 & \\
\hline Gr90 & $115,(\mathrm{AC}) 12$ & 106 and 121 & 104 and 119 & $\begin{array}{c}\text { Not } \\
\text { determined }\end{array}$ & N/A & N/A & $\begin{array}{l}\text { Yes: } 106, \\
\text { Rare: } 121\end{array}$ & 106106 & 106121 & 121121 & 106117 \\
\hline Gr91 & 112, (GT)5 & 114 & 111 & 113 & (GT)6 & MH820364 & Yes:114 & 114114 & 114116 & 116116 & $\ldots$ \\
\hline Gp118 & 133, (TCCG)4 & 123 & 124 & 126 & (TCCG)4 & MH820365 & $\begin{array}{l}\text { No: } 127 \text { is } \\
\text { most common }\end{array}$ & 123123 & $\ldots$ & $\ldots$ & $\cdots$ \\
\hline Gr85 & 123, (CA)7 & 125 & 125 & 127 & $(\mathrm{CA}) 3 \mathrm{C}(\mathrm{CA}) 7$ & MH820366 & Yes: 125 & 125125 & $\ldots$ & $\ldots$ & $\ldots$ \\
\hline Gr75 & $147,(\mathrm{CA}) 10$ & 137 & 137 & 140 & (CA)7 & MH820367 & Yes: 137 & 137137 & $\ldots$ & $\ldots$ & $\ldots$ \\
\hline Gp116 & 141, (CGTC)4 & $131 / 139$ & $131 / 139$ & $133 / 141$ & $\begin{array}{l}\text { (CGTC)2, } \\
\text { (CATT)5/7 }\end{array}$ & $\begin{array}{l}\text { MH820368, } \\
\text { MH820369 }\end{array}$ & Yes: 131 & 131131 & 131139 & 139139 & $\cdots$ \\
\hline Gr67 & $180,(\mathrm{GT}) 5$ & 169 & 168 & 168 & (GT)3 & MH820380 & Yes: 169 & 166166 & 166169 & 169169 & $\ldots$ \\
\hline Gr50 & $322,(\mathrm{ACCA}) 5$ & 317 & 317 & $\begin{array}{c}\text { Not } \\
\text { determined }\end{array}$ & N/A & N/A & Yes: 317 & 317317 & $\cdots$ & $\ldots$ & $\cdots$ \\
\hline
\end{tabular}

a Bold text indicates the alleles that were successfully sequenced.

b $\mathrm{N} / \mathrm{A}=$ not available.

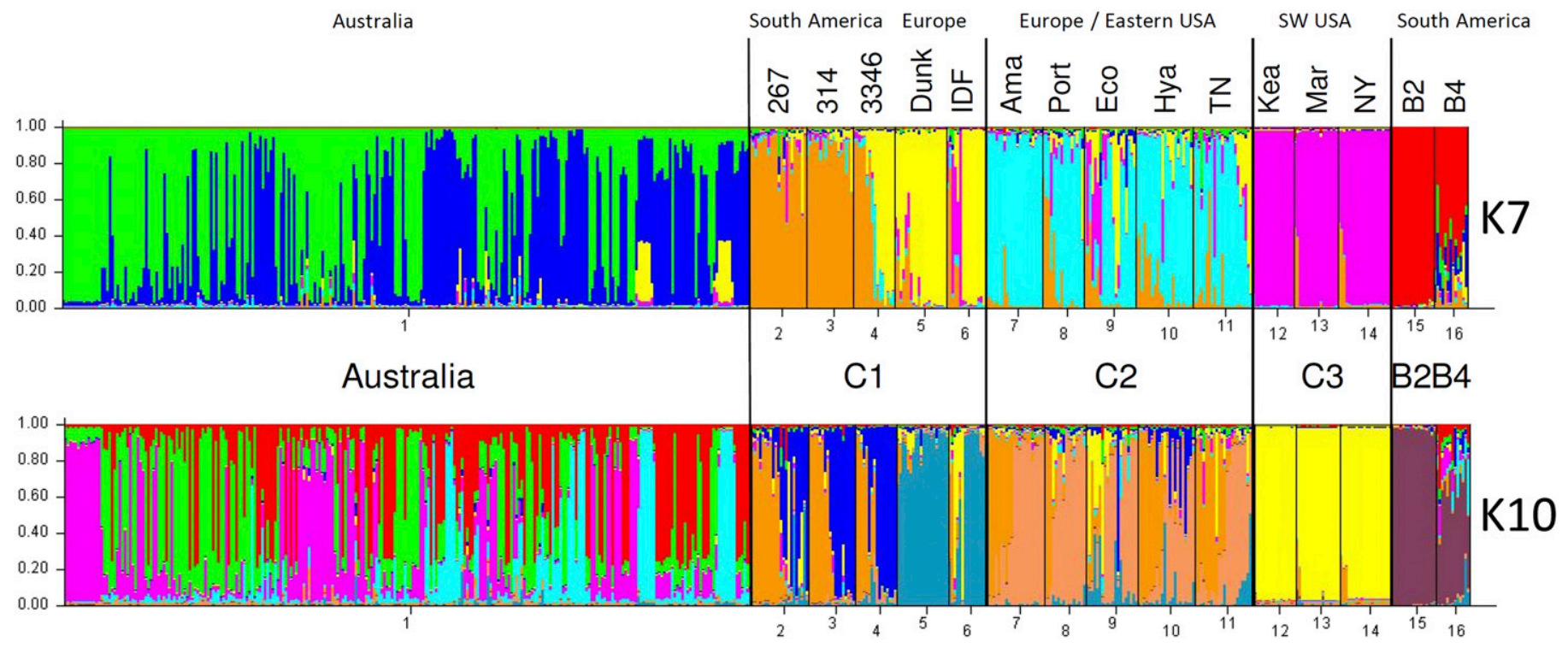

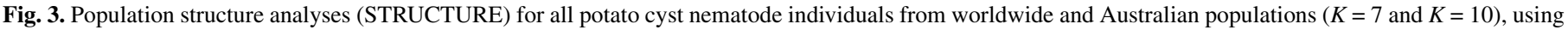
data from nine microsatellite loci. Cluster names B2, B4, and C1 to C3 are from Boucher et al. (2013). 


\section{DISCUSSION}

Our study clearly demonstrates that PCN in Victoria, Australia, possesses limited genetic variation compared with known potential source populations (Boucher et al. 2013). In contrast to the hypothesis proposed by Nambiar et al. (2008), the populations in
Victoria do not appear to indicate multiple independent origins. All populations screened appeared to share genetic variation, suggesting a single introduction and subsequent limited spread. Although we could not match the Australian PCN to any particular worldwide population, the microsatellite and ITS genetic variation observed in Australian PCN is present within European PCN populations; thus,

A

B

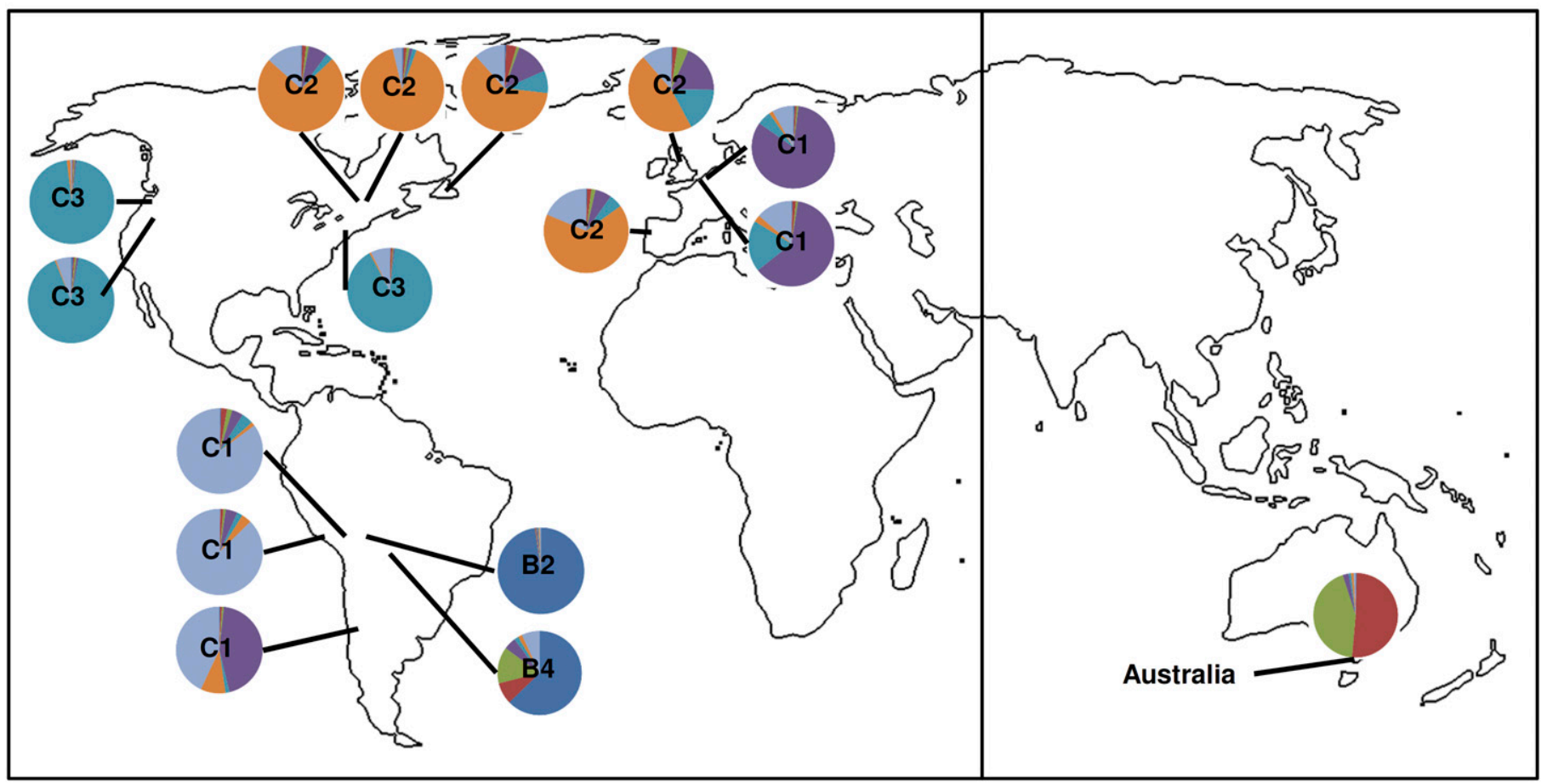

Fig. 4. World map showing distribution of genetic groups determined by STRUCTURE analyses using nine microsatellite loci. A, Microsatellite data from Boucher et al. (2013) reanalyzed using only nine loci. Cluster names, B2, B4, and C1 to C3 are from Boucher et al. (2013). B, Microsatellite data obtained from Australian populations (current study).
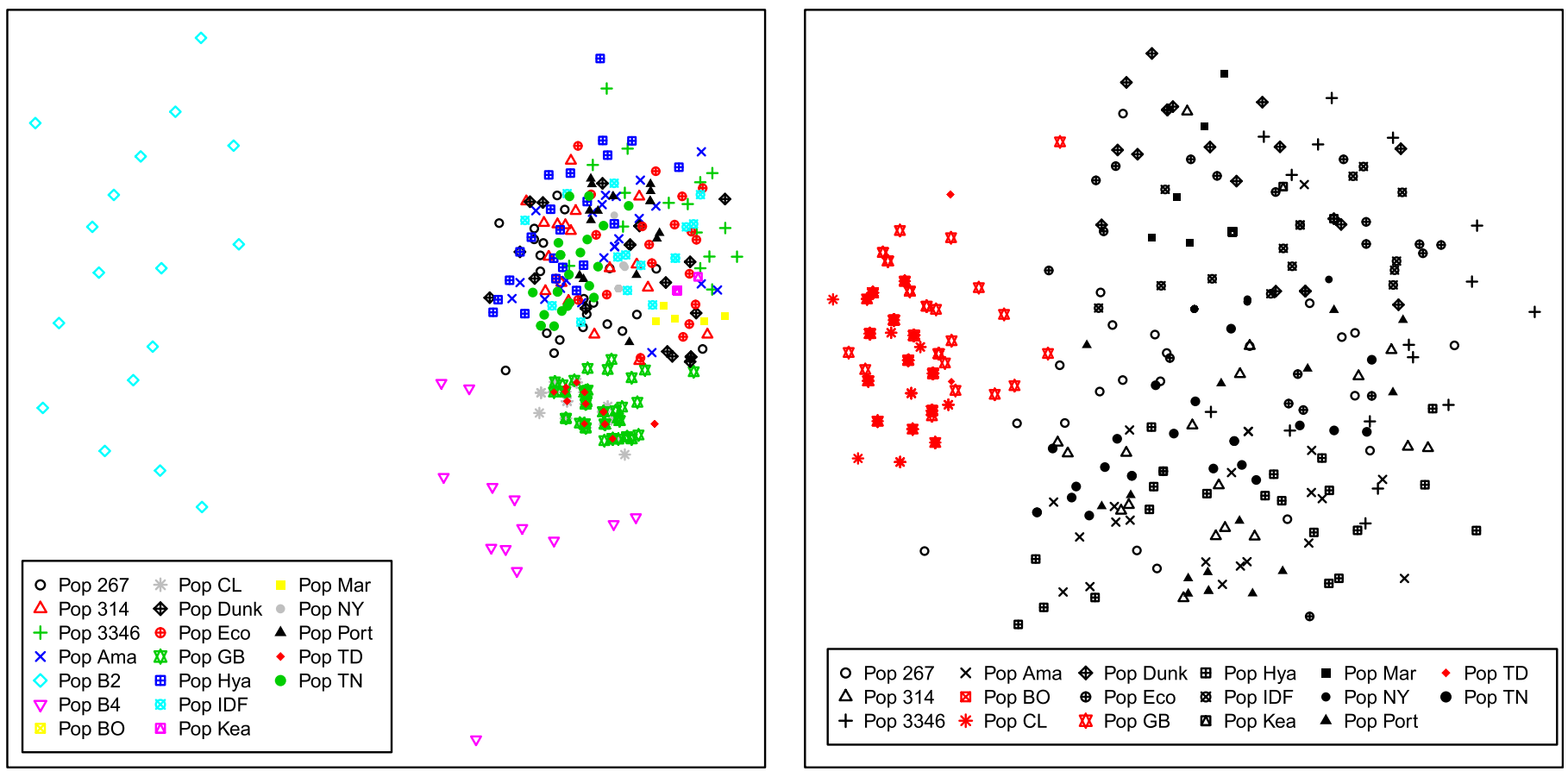

Fig. 5. Nonmetric multidimensional scaling ordinations illustrating genetic variation, similarities, and differences among samples and populations. Each point represents a single sample. All samples are included in the ordination on the left whereas, on the right, the outlier populations B2 and B4 have been left out to better illustrate the remaining populations and the Australian populations shown in a different color. 
Europe could be a possible source, as has been historically believed. Interestingly, because the earliest Victorian detections were from land used for market gardens, there has been anecdotal speculation that the nematode may have arrived on flower bulbs imported from the Netherlands. Unfortunately, no G. rostochiensis microsatellite data were available from the Netherlands for comparison at the time of our study.

PCN is a declared notifiable pest in Victoria and, until 2012, strict movement restrictions were in place for any host material, soil, and equipment within PCN control areas (i.e., within a $20-\mathrm{km}$ radius from a PCN-positive parcel of land). Since 2013, a Risk-Based Regulatory Reform Model has been utilized instead, with regulated movement restrictions based on pathways in the production and supply chain that have been identified as being at high risk for the spread and establishment of PCN (Agriculture Victoria 2017). Since the first PCN detection in 1991, extensive surveillance based on soil sampling has taken place across all potato-growing regions of Victoria. All PCN soil testing has been undertaken by Agriculture Victoria's diagnostic laboratory, Crop Health Services, and, with more than 57,000 soil samples tested, only 66 parcels of land have tested positive for PCN. All of the positive detections are within a small region south and east of Melbourne. Therefore, the strict quarantine control measures involving increased hygiene and enforcing restricted movement appear to have been effective in stopping the spread of PCN, with the last detections from new properties from each control area being in 2007 (Koo Wee Rup and Boneo), 2011 (Thorpdale), and 2014 (Gembrook). In addition, Australia's strict requirements around potato imports since the 1980s (DAWR 2013) appear to have been effective in preventing any further introductions of the pest, with Australian PCN possessing stable ITS and microsatellite genetic variation both temporally and spatially.

Many previously examined PCN populations worldwide appear to contain microsatellite allelic variation within the population that is not especially common in other populations (e.g., C3 populations share a very high frequency of 137,117 , and 139 alleles at Gr75, Gr90, and Gp116 loci, respectively) (Boucher et al. 2013). However, Australian PCN populations appear to possess alleles that are relatively common worldwide but are present at unusual

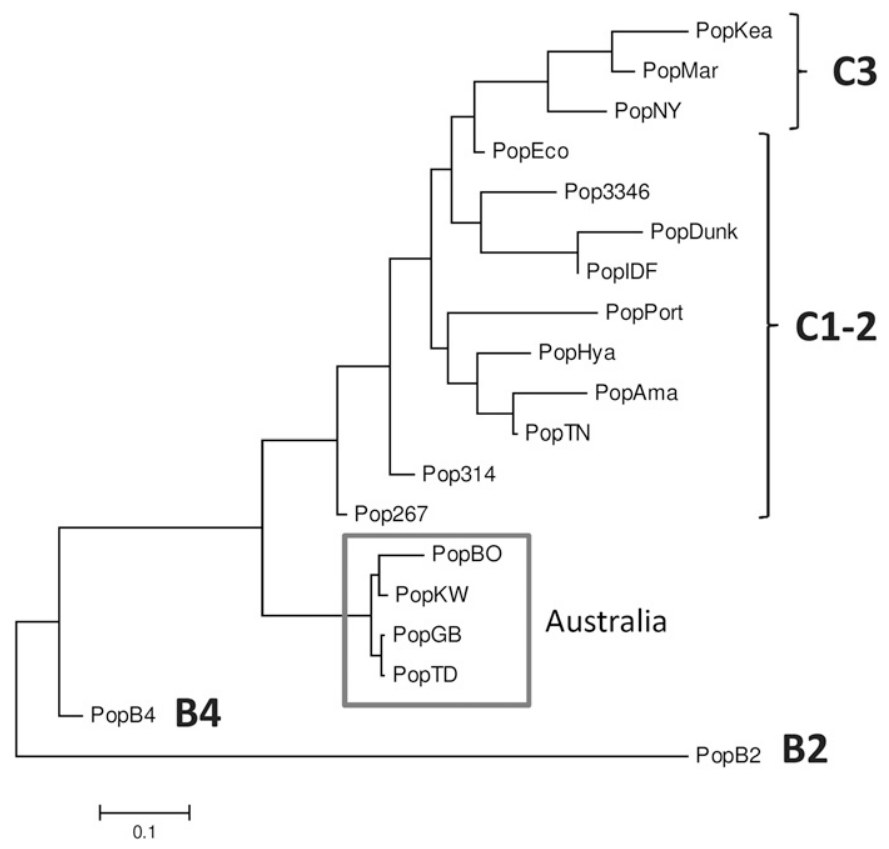

Fig. 6. Neighbor-joining tree of relationships between worldwide and Australian populations (indicated by box). Cluster names B2, B4, and $\mathrm{C} 1$ to $\mathrm{C} 3$ are from Boucher et al. (2013). frequencies, which differentiates Australian populations from all other known worldwide populations.

Direct DNA sequencing of homozygous alleles revealed the absolute size (in base pairs) of the microsatellite alleles scored in the

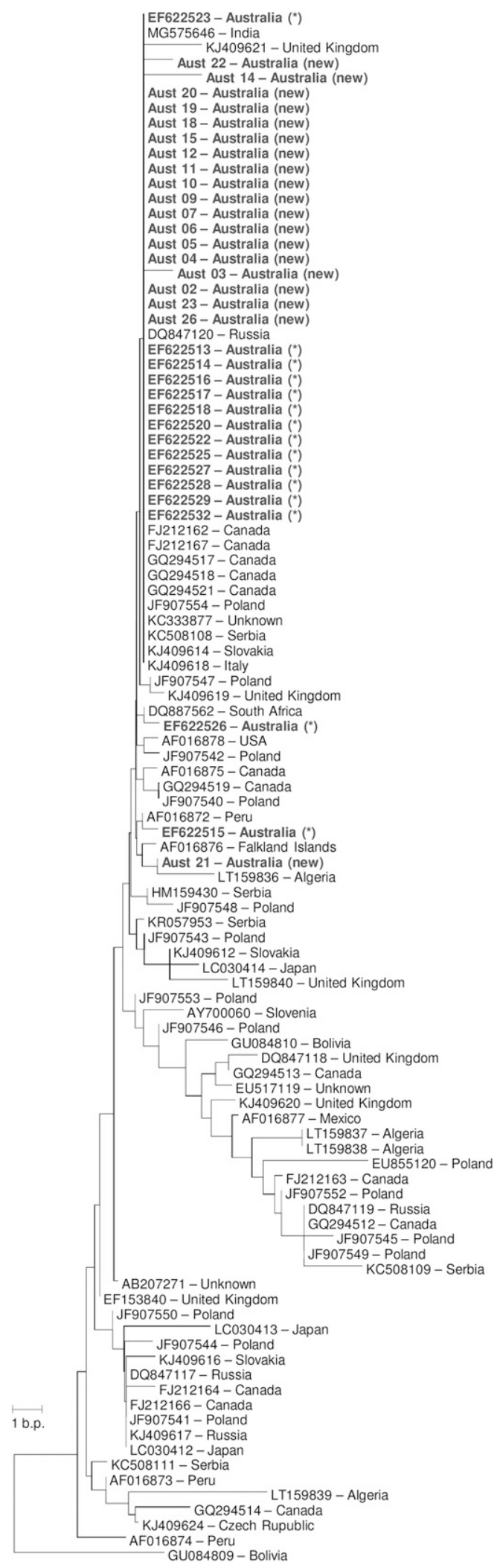

Fig. 7. Neighbor-joining tree of genetic relationships among worldwide Globodera rostochiensis potato cyst nematode populations assessed from internal transcribed spacer DNA sequence data $(730 \mathrm{bp})$. Australian populations are indicated in bold, with Australian specimens examined in the current study labeled as "new" and those from Nambiar et al. (2008) indicated by an asterisk (*). 
current study. However, the microsatellite allele size required adjustment in our study to provide the best chance of matching the Australian data with known allele sizes from other worldwide populations (Boucher et al. 2013). It is common for small size shifts to be observed between alleles scored between different laboratories (Ellis et al. 2011; Moran et al. 2006), which are believed to result from incremental differences in determining the size of alleles between equipment and screening platforms. Size shifts of microsatellite alleles have even been previously shown to occur with changes between different fluorophores (Sutton et al. 2011).

As in previous studies of the related G. pallida (Plantard et al. 2008), it appears that the amount of genetic variability observed

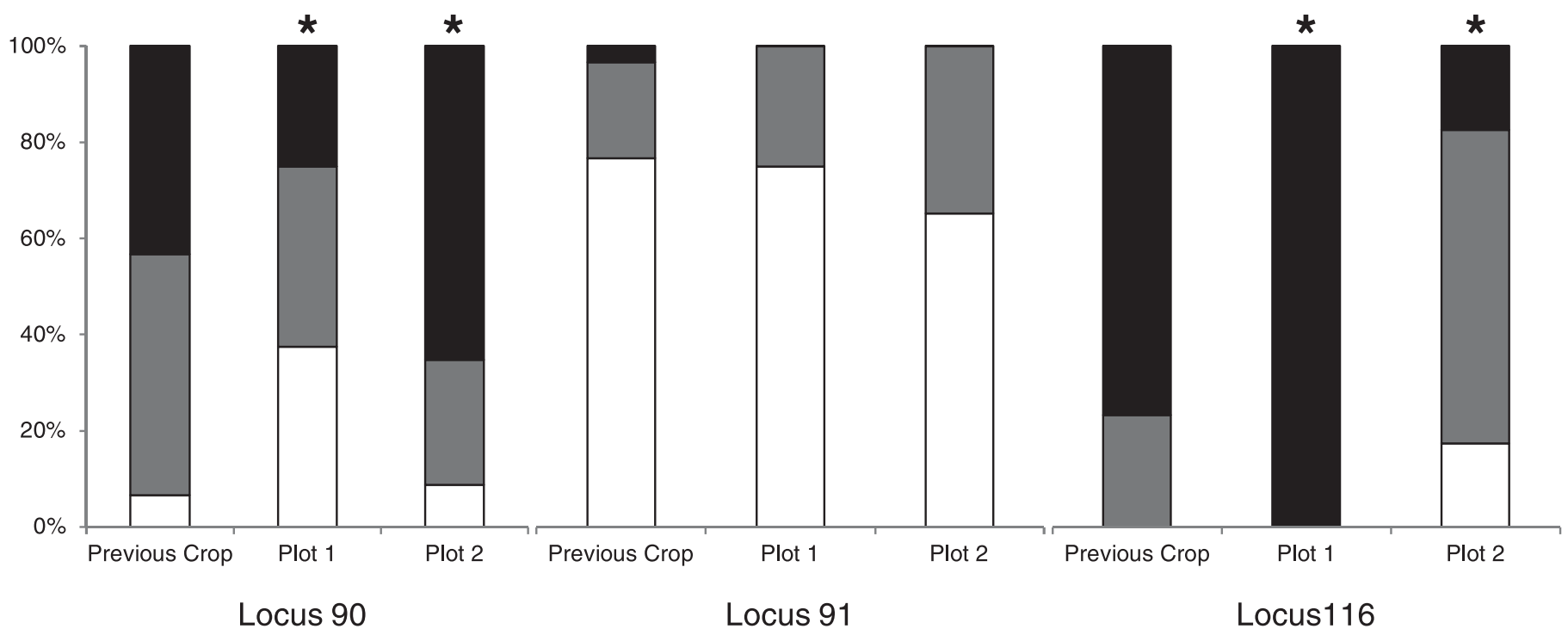

Fig. 8. Genotype frequencies of three variable microsatellites ( $\mathrm{Gr} 90$, Gr 91, and Gr 116) in three plots of different potato varieties, collected from Gembrook between 2008 and 2010. Previous crop $=$ original susceptible crop being grown on property $(n=30)$, Plot $1=$ susceptible Trent variety $(n=8)$, and Plot $2=$ resistant Crop13 variety $(n=23)$. Gray indicates heterozygotes and asterisks indicate significant departures from Hardy-Weinberg equilibrium.

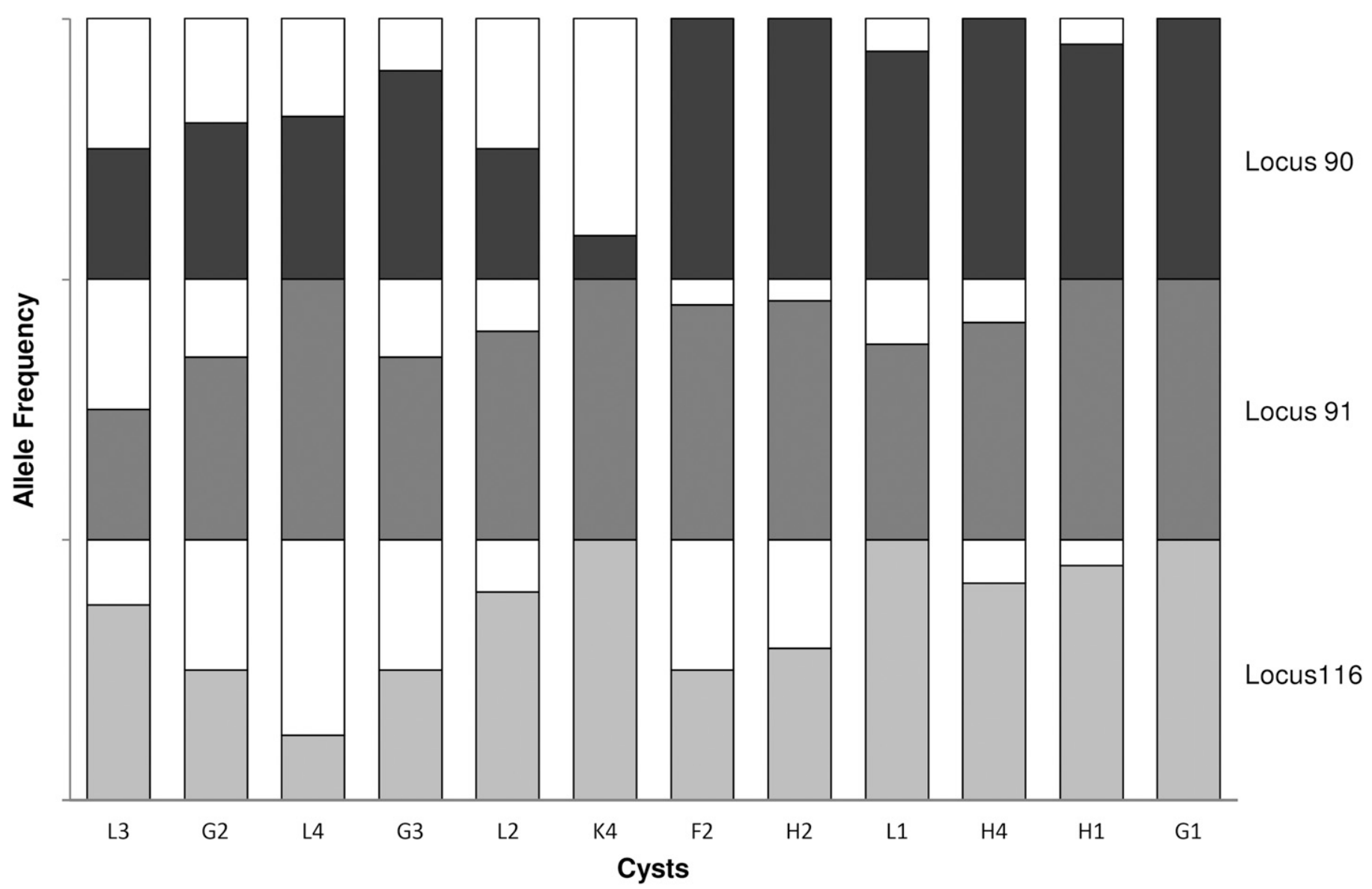

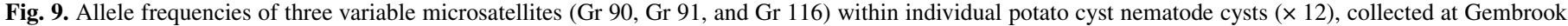
between 2008 and 2010. Three to six juveniles per cyst, $n=56$ total. 
within individual PCN cysts can be similar to that observed among entire populations. In the current study, a great deal of variation was observed in the frequency of alleles present within and between cysts, with changes in allele frequencies differing from HardyWeinberg equilibrium, possibly relating to the crop variety being utilized by PCN populations.

Our study was based on PCN samples collected through biosecurity sampling and retained (dry) in a long-term reference collection (VPRI, Agriculture Victoria), making our study different from most previous studies which have specifically collected PCN samples through short-term targeted surveys (Boucher et al. 2013; Bulman and Marshall 1997; Grenier et al. 2001; Mimee et al. 2015; Nambiar et al. 2008; Picard et al. 2004; Plantard et al. 2008). The reference collection samples collected over an extended period provide a historical element to our study. The number of samples genotyped was much less than the number of cysts extracted and examined, with the success rate of DNA genotyping greatly reduced with sample age. This is probably due to the need for juvenile PCN to be well preserved within cysts. Larvae within cysts preserved dry in the laboratory may perish sooner than those within soilborne cysts in the field, where larvae can remain viable for more than 20 years (Perry et al. 2013; Turner 1996). Indeed, some older samples from areas of interest in Australia, including samples from Western Australia, could not be used because they were found to have been not suitably preserved for DNA analyses (i.e., in formalin). Other regions such as New Zealand and the Netherlands represent current gaps in our knowledge of PCN population genetic relationships, which will hopefully be addressed through future studies.

The molecular assessments conducted in our study have revealed very little differentiation between Victorian populations, which share ITS DNA sequence and microsatellite allelic variation, with differences between local regions probably reflecting changes in allele frequencies over time. Our study suggests a probable single localized introduction into Victoria followed by limited spread to nearby areas, with Australian PCN appearing genetically distinct from populations previously sampled worldwide. Additionally, all of the Australian ITS sequences were of $G$. rostochiensis, confirming that $G$. pallida has not been recorded in Australia (Faggian et al. 2012). Any new exotic incursions, which potentially might bring in additional PCN pathotypes, should now be easily differentiated from existing established local PCN populations.

\section{ACKNOWLEDGMENTS}

We thank B. Hayes for assisting with the design of the genotyping study; T. Slater for providing industry context and data (Agriculture Victoria); D. Mansell, T. Burgess, G. D'Arcy, D. de Boer, and G. Berg (Biosecurity, Agriculture Victoria) for assisting with historical data and PCN sampling; L. Nambiar (Agriculture Victoria) for processing many of the PCN samples used in this study; the many potato growers who allowed access for PCN surveys; and those who read and provided valuable comments on a draft of this article.

\section{LITERATURE CITED}

Agriculture Victoria. 2017. Potato Cyst Nematode Management Policy for Victoria. Online publication. http://agriculture.vic.gov.au/agriculture/pestsdiseases-and-weeds/pest-insects-and-mites/potato-cyst-nematode

Alenda, C., Montarry, J., and Grenier, E. 2014. Human influence on the dispersal and genetic structure of French Globodera tabacum populations. Infect. Genet. Evol. 27:309-317.

Anderson, M. J. 2001. A new method for non-parametric multivariate analysis of variance. Austral Ecol. 26:32-46.

Anon. 2007. Directives, Council Directive 2007/33/EC of 11 June 2007 on the control of potato cyst nematodes and repealing Directive 69/465/EEC. Off. J. Eur. Communities Legis. 156:12-22.

AUSVEG. 2012. Australian National Potato Cyst Nematode Management Plan. Final Plan. Online publication. Australian Potato Industry. http:// www.potatoessa.com.au/wp-content/uploads/PCN-Plan-full-version_ June-2012.pdf
AUSVEG. 2018. Vegetable Industry Export Snapshot. Online publication. https://ausveg.com.au/export/\#vegetable_industry_export_snapshot3cd6Ocba

Been, T. H., and Schomaker, C. H. 2013. Distribution patterns and sampling. Pages 331-358 in: Plant Nematology, 2nd ed. R. N. Perry and M. Moens, eds. CAB International, Wallingford, UK.

Boucher, A. C., Mimee, B., Montarry, J., Bardou-Valette, S., Belair, G., Moffett, P., and Grenier, E. 2013. Genetic diversity of the golden potato cyst nematode Globodera rostochiensis and determination of the origin of populations in Quebec, Canada. Mol. Phylogenet. Evol. 69:75-82.

Brodie, B. B. 1998. Potato. Pages 567-594 in: Plant and Nematode Interactions. Agron. Monogr. No. 36. K. R. Barker, G. A. Pederson, and G. L. Windham, eds. American Society of Agronomy, Madison, WI.

Bulman, S. R., and Marshall, J. W. 1997. Differentiation of Australasian potato cyst nematode $(\mathrm{PCN})$ populations using the polymerase chain reaction (PCR). N. Z. J. Crop Hortic. Sci. 25:123-129.

CABI. 2016. Invasive species compendium; Globodera rostochiensis (yellow potato cyst nematode). Online publication. http://www.cabi.org/isc/datasheet $/ 27034$

Collins, S. J., Marshall, J. M., Zhang, X. H., and Vanstone, V. A. 2010. Area freedom from Globodera rostochiensis in Western Australia. Asp. Appl. Biol. 103:55-62.

Cotton, J. A., Lilley, C. J., Jones, L. M., Kikuchi, T., Reid, A. J., Thorpe, P., Tsai, I. J., Beasley, H., Blok, V., Cock, P. J. A., Eves-van den Akker, S., Holroyd, N., Hunt, M., Mantelin, S., Naghra, H., Pain, A., Palomares-Rius, J., Zarowiecki, M., Berriman, M., Jones, J. T., and Urwin, P. E. 2014. The genome and life-stage specific transcriptomes of Globodera pallida elucidate key aspects of plant parasitism by a cyst nematode. Genome Biol. 15: R43.

DAWR. 2013. Biosecurity Advice 2013/21 - Final review of policy: Importation of potato (Solanum tuberosum) propagative material in Australia. Online publication. Department of Agriculture and Water Resources, Australian Government. http://www.agriculture.gov.au/biosecurity/risk-analysis/ memos/2013/final-potato

DEDJTR. 2016. Plant Quarantine Manual, Version 26.3. Department of Economic Development, Jobs, Transport and Resources, State Government of Victoria, Australia.

DEPI. 2013. Notice to producers, processors and packers of potato cyst nematode host produce: National reforms to PCN management, 1 November 2013. Online publication. Department of Environment and Primary Industries, Victorian Government, Melbourne, Australia. https://www. auspica.org.au/wp-content/uploads/2018/02/Notice-to-producers-processorsand-packers-of-Potato-Cyst-Nematode-host-produce-final.pdf

DPIPWE. 2015. Plant Biosecurity Manual Tasmania, 2016 ed. Department of Primary Industries, Parks, Water and Environment, Tasmania.

Ellis, J. S., Gilbey, J., Armstrong, A., Balstad, T., Cauwelier, E., Cherbonnel, C., Consuegra, S., Coughlan, J., Cross, T. F., Crozier, W., Dillane, E., Ensing, D., García de Leániz, C., García-Vázquez, E., Griffiths, A. M., Hindar, K., Hjorleifsdottir, S., Knox, D., Machado-Schiaffino, G., McGinnity, P., Meldrup, D., Nielsen, E. E., Olafsson, K., Primmer, C. R., Prodohl, P., Stradmeyer, L., Vähä, J. P., Verspoor, E., Wennevik, V., and Stevens, J. R. 2011. Microsatellite standardization and evaluation of genotyping error in a large multi-partner research programme for conservation of Atlantic salmon (Salmo salar L.). Genetica 139: 353-367.

EPPO/CABI. 1997. Globodera rostochiensis and Globodera pallida. Pages 601-606 in: Quarantine Pests for Europe, 2nd ed. I. M. Smith, D. G. McNamara, P. R. Scott, and M. Holderness, eds. CAB International, Wallingford, UK.

Faggian, R., Powell, A., and Slater, A. T. 2012. Screening for resistance to potato cyst nematode in Australian potato cultivars and alternative solanaceous hosts. Austral. Plant Pathol. 41:453-461.

Falush, D., Stephens, M., and Pritchard, J. K. 2003. Inference of population structure using multilocus genotype data: Linked loci and correlated allele frequencies. Genetics 164:1567-1587.

Fenwick, D. W. 1940. Methods for the recovery and counting of cysts of Heterodera schachtii from soil. J. Helminthol. 18:155-172.

Grenier, E., Bossis, M., Fouville, D., Renault, L., and Mugniery, D. 2001. Molecular approaches to the taxonomic position of Peruvian potato cyst nematodes and gene pool similarities in indigenous and imported populations of Globodera. Heredity 86:277-290.

Guy, G., Woodward, J., and Hinch, J. M. 1992. Globodera rostochiensis and possibly G. pallida in Australia. J. Nematol. 24:594.

HIA. 2018. Australian Horticulture Statistics Handbook-Vegetables 2016/17. Horticulture Innovation Australia Limited, Sydney, Australia.

Hinch, J. M. 1991. National sampling strategies and standards for detection of potato cyst nematode. Pages126-131 in: Potato Cyst Nematode: Impact on Australian Horticulture and a Proposed National Strategy. Ind. Rep. No. 6. Horticultural Policy Research Council, Canberra, Australia. 
Hinch, J. M., Alberdi, F., Smith, S. C., Woodward, J. R., and Evans, K. 1998. Discrimination of European and Australian Globodera rostochiensis and G. pallida pathotypes by high performance capillary electrophoresis. Fundam. Appl. Nematol. 21:123-128.

Hockland, S., Inserra, R., and Kohl, L. M. 2013. International plant healthPutting legislation into practice. Pages 359-382 in: Plant Nematology, 2nd ed. R. N. Perry and M. Moens, eds. CAB International, Wallingford, UK.

Hodda, M., and Cook, D. C. 2009. Economic impact from unrestricted spread of potato cyst nematodes in Australia. Phytopathology 99:1387-1393.

Howlett, B. J., Brownlee, A. G., Guest, D. I., Adcock, G. J., and McFadden, G. I. 1992. The 5S ribosomal RNA gene is linked to large and small subunit ribosomal RNA genes in the oomycetes, Phytophthora vignae, P. cinnamomi, P. megasperma f. sp. glycinae and Saprolegnia ferax. Curr. Genet. 22:455-461.

Kepich, D. 2011. Golden nematode program 2011. Online publication. http:// www.hort.cornell.edu/expo/proceedings/2012/Potato/Potato\%20Kepich.pdf

Kort, J., Ross, H., Stone, A. R., and Rumpenhorst, H. J. 1977. An international scheme for identifying and classifying pathotypes of potato cyst nematodes Globodera rostochiensis and G. pallida. Nematologica 23:333-339.

Kumar, S., Stecher, G., and Tamura, K. 2016. MEGA7: Molecular Evolutionary Genetics Analysis version 7.0 for bigger datasets. Mol. Biol. Evol. $33: 1870-1874$

Laskie, A. 2018. Seed potatoes: New trade deal opens doors to Indonesia for farmers. Online publication. The Weekly Times. https://www.weeklytimesnow. com.au/agribusiness/horticulture/seed-potatos-new-trade-deal-opens-doors-toindonesia-for-farmers/news-story/875603c3c1ce8b0ebe76e619127c4536

Lehman, P. S. 2004. Cost-benefits of nematode management through regulatory programs. Pages 1133-1178 in: Nematology: Advances and Perspectives. Volume 2: Nematode Management and Utilization. Z. X. Chen, S. Y. Chen, and D. W. Dickson, eds. Tsinghua University Press, Beijing, China and CAB International, Wallingford, UK

Mai, W. F. 1977. Worldwide distribution of potato-cyst nematodes and their importance in crop production. J. Nematol. 9:30-34.

Marshall, J. W. 1998. Potato cyst nematodes (Globodera species) in New Zealand and Australia. Pages 353-394 in: Potato Cyst Nematodes, Biology, Distribution and Control. R. J. Marks and B. B. Brodie, eds. CAB International, Wallingford, UK.

Mimee, B., Andersen, R., Belair, G., and Rott, M. 2014. Impact of quarantine procedures on weed biodiversity and abundance: Implications for the management of the golden potato cyst nematode, Globodera rostochiensis. Crop Prot. 55:21-27.

Mimee, B., Duceppe, M., Veronneau, P., Lafond-Lapalme, J., Jean, M., Belzile, F., and Belair, G. 2015. A new method for studying population genetics of cyst nematodes based on Pool-Seq and genomewide allele frequency analysis. Mol. Ecol. Resour. 15:1356-1365.

Minchin, P. R. 1987. An evaluation of relative robustness of techniques for ecological ordinations. Vegetatio 69:89-107.

Moens, M., Perry, R. N., and Jones, J. T. 2018. Cyst nematodes-Life cycle and economic importance. Pages 1-26 in: Cyst Nematodes. M. Moens, R. N. Perry, and T. J. Jones, eds. CAB International, Wallingford, UK.

Moran, P., Teel, D. J., LaHood, E. S., Drake, J., and Kalinowski, S. 2006. Standardising multi-laboratory microsatellite data in Pacific salmon: An historical view of the future. Ecol. Freshwat. Fish 15:597-605

Nambiar, L., Cunnington, J., and Quader, M. 2008. Conventional and real-time PCR-based species identification and diversity of potato cyst nematodes (Globodera spp.) from Victoria, Australia. Nematology 10:471-478.

Oksanen, J., Blanchet, F. G., Kindt, R., Legendre, P., Minchin, P. R., O’Hara, R. B., Simpson, G. L., Solymos, P., Henry, M., Stevens, H., and Wagner, H. 2016. vegan: Community Ecology Package. Online publication. R package, version 2.3-5. https://cran.r-project.org/web/packages/vegan/index.html

PBPI-BQ. 2016. Queensland Biosecurity Manual-Edition 2016, Version 1. Plant Biosecurity and Product Integrity sub-program of Biosecurity Queensland, Department of Agriculture and Fisheries, Queensland Government.

PBPPIS. 2016. Plant Quarantine Manual for New South Wales-Version 1.0. Plant Product Integrity and Standards Unit, New South Wales Department of Primary Industries, Orange, NSW, Australia.

Peakall, R., and Smouse, P. E. 2006. GenAlEx6: Genetic analysis in Excel. Population genetic software for teaching and research. Mol. Ecol. Notes 6:288-295.

Peakall, R., and Smouse, P. E. 2012. GenAlEx6.5: Genetic analysis in Excel. Population genetic software for teaching and research-An update. Bioinformatics 28:2537-2539.

Pendrigh, J. 1993. Potato Cyst Nematode: Impact on Australian Horticulture and a Proposed National Strategy. Ind. Rep. No. 6. Horticultural Policy Council. Commonwealth of Australia.

Perry, R. N., Wright, D. J., and Chitwood, D. J. 2013. Reproduction, physiology and biochemistry. Pages 219-245 in: Plant Nematology, 2nd ed. R. N. Perry and M. Moens, eds. CAB International, Wallingford, UK.
Persley, D., Cooke, T., and House, S. 2010. Diseases of Vegetable Crops in Australia. CSIRO Publishing, Collingwood, VIC, Australia.

Picard, D., Plantard, O., Scurrah, M., and Mugniery, D. 2004. Inbreeding and population structure of the potato cyst nematode (Globodera pallida) in its native area (Peru). Mol. Ecol. 13:2899-2908.

Pickup, J., and Hockland, S. 2002. Potato cyst nematodes-A technical overview for Scotland. https://www.google.com.au/url?sa=t\&rct=j\&q= \&esrc $=$ s \&source $=$ web $\& c d=1 \&$ ved $=2$ ahUKEwj3j67csofg AhUHu48KHY1YCKwQFjAAegQIARAC\&url=https $\% 3 \mathrm{~A} \% 2 \mathrm{~F} \% 2 \mathrm{Fwww}$.researchgate.net $\%$ 2Fprofile\%2FHouda_Kawas\%2Fpost\%2FDiapause_Re-occurrence_in_ Potato_Cyst_Nematodes\%2Fattachment\%2F59d64a2b79197b80779a4807\% 2FAS\%253A474235933073408\%25401490078065153\%2Fdownload\%2Ftech scotland.pdf\&usg=AOvVaw1f4dcGZ2gfhV-fzeEqno04

PIRSA. 2015. Plant Quarantine Standard South Australia-V 11.1. Primary Industries and Regions South Australia, Government of South Australia. Glenside, South Australia.

Plantard, O., Picard, D., Valette, S., Scurrah, M., Grenier, E., and Mugniery, D. 2008. Origin and genetic diversity of Western European populations of the potato cyst nematode (Globodera pallida) inferred from mitochondrial sequences and microsatellite loci. Mol. Ecol. 17:2208-2218.

Pritchard, J. K., Stephens, M., and Donnelly, P. 2000. Inference of population structure using multilocus genotype data. Genetics 155:945-959.

R Core Team. 2017. R: A Language and Environment for Statistical Computing. Online publication. R Foundation for Statistical Computing, Vienna. http://www.R-project.org/

Reid, A., Kenyon, D. M., Evans, F. F., Mulholland, V., Pickup, J., Blok, V. C., Paterson, A., and Phillips, M. S. 2010. Development of a high-throughput method for the detection and species determination of PCN. (3rd Symp. Potato Cyst Nematodes) Asp. Appl. Biol. 103:13-16

Riggs, R. D., and Schuster, R. P. 1998. Management. Pages 388-416 in: The Cyst Nematodes. S. B. Sharma, ed. Kluwer Academic Publishers, Dordrecht, The Netherlands.

Spears, J. F. 1968. The Golden Nematode Handbook, Survey, Laboratory, Control and Quarantine Procedures. USDA Handbook. Agricultural Research Service, United States Department of Agriculture, Washington, D.C.

Stanton, J. M. 1986. First record of potato cyst nematode, Globodera rostochiensis, in Australia. Austral. Plant Pathol. 15:87.

Sutton, J. T., Robertson, B. C., and Jamieson, I. G. 2011. Dye shift: A neglected source of genotyping error in molecular ecology. Mol. Ecol. Resour. 11:514-520.

Turner, S. J. 1996. Population decline of potato cyst nematodes (Globodera rostochiensis, G. pallida) in field soils in Northern Ireland. Ann. Appl. Biol. 129:315-322.

Turner, S. J., and Evans, K. 1998. The origins, global distribution and biology of potato cyst nematodes (Globodera rostochiensis Woll. and Globodera pallida Stone). Pages 2-26 in: Potato Cyst Nematodes, Biology, Distribution and Control. R. J. Marks and B. B. Brodie, eds. CAB International, Wallingford, UK

Turner, S. J., and Subbotin, S. A. 2013. Cyst nematodes. Pages 109-143 in: Plant Nematology, 2nd ed. R. N. Perry and M. Moens, eds. CAB International, Wallingford, UK

USDA. 2014. Canada and United States guidelines on surveillance and phytosanitary actions for the potato cyst nematodes Globodera rostochiensis and Globodera pallida. Online publication. United States Department of Agriculture. https://www.aphis.usda.gov/plant_health/plant_pest_info/nematode/downloads/potato_guidelines.pdf

van Riel, H. R., and Mulder, A. 1998. Potato cyst nematodes (Globodera species) in western Europe. Pages 271-298 in: Potato Cyst Nematodes, Biology, Distribution and Control. R. J. Marks and B. B. Brodie, eds. CAB International, Wallingford, UK.

ViCSPA. 2015. Victorian potato industry strategic plan 2015/16-2019/20. Online publication. Victorian Certified Seed Potato Authority. https://www. auspica.org.au/wp-content/uploads/2018/02/Strategic-Plan-Victorian-PotatoIndustry-Final.pdf

White, T. J., Bruns, T., Lee, S., and Taylor, J. 1990. Amplification and direct sequencing of fungal ribosomal RNA genes for phylogenetics. Pages 315-322 in: PCR Protocols: A Guide to Methods and Applications. M. A. Gelfard, D. H. Sninsky, and T. J. White, eds. Academic Press, San Diego, CA.

Whitehead, A. G., and Turner, S. J. 1998. Management and regulatory control strategies for potato cyst nematodes (Globodera rostochiensis and Globodera pallida). Pages 135-152 in: Potato Cyst Nematodes, Biology, Distribution and Control. R. J. Marks and B. B. Brodie, eds. CAB International, Wallingford, UK

Zapala, M. A., and Schork, N. J. 2006. Multivariate regression analysis of distance matrices for testing associations between gene expression patterns and related variables. Proc. Natl. Acad. Sci. USA 103:19430-19435. 